
\section{Sciencepark Research, Organization \& Counseling Language Teaching}

Volume 07, Issue 2, (2017)

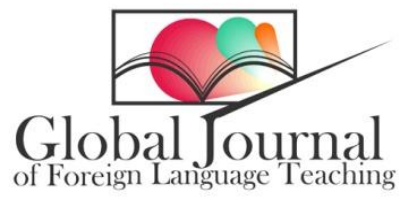

www.giflt.eu

\title{
Message from Editor
}

Dear Readers,

It is a great honor for us to publish 7th volume, 2nd issue of Global Joumal of Foreign Language Teaching (GJFLT).

Global Journal of Foreign Language Teaching (GJFLT) welcomes original empirical investigations and comprehensive literature review articles focusing on foreign language teaching and topics rel ated to linguistics. The journal is an international journal published quarterly and it is a platform for presenting and discussing the emerging developments in foreign language teaching in an international arena.

A total number of ten (10) manuscripts were submitted for this issue and each paper has been subjected to double-blind peer review process by the reviewers specialized in the related field. At the end of the review process, a total number of four (4) high quality research papers were selected and accepted for publication.

Aim of this issue is to give the researchers an opportunity to share the results of their academic studies. There are different research topics discussed in the articles. For example, Alexandra-Valeria Popescu, Marion-Ivonne Cohen-Vida and Elena Claudia Constantin examined whether ESP students need grammar or not. In addition, Arijeta Selimi investigated syllabus design based on the principles of multilingualism in teaching in multilingual education. Rabia Borekci and Fatih Yavuz discussed foreign language listening anxiety among Turkish EFL learners. Finally, Islam Namazian Doost and Soheila Tahmasbi examined the effect of peripheral learning on elementary EFL learners' grammar improvement based on the case of prepositions of time and place. The topics of the next issue will be different. We are trying to serve you with our journal with a rich knowledge through which different kinds of topics will be discussed in 2017 issues.

We present many thanks to all the contributors who helped us to publish this issue.

Best regards,

Prof. Dr. Ali Rahimi

Editor - in Chief 